\title{
Comparative Proteomic Analysis of Candida albicans and Candida glabrata
}

\author{
Thottethodi Subrahmanya Keshava Prasad • Shivakumar Keerthikumar • \\ Raghothama Chaerkady • Kumaran Kandasamy • Santosh Renuse • \\ Arivusudar Marimuthu • Abhilash Karavattu Venugopal • Joji Kurian Thomas • \\ Harrys K. C. Jacob • Renu Goel • Harsh Pawar • Nandini A. Sahasrabuddhe • \\ Venkatarangaiah Krishna • Bipin G. Nair • Marjan Gucek • Robert N. Cole • \\ Raju Ravikumar • H. C. Harsha • Akhilesh Pandey
}

Published online: 5 October 2010

(C) Springer Science+Business Media, LLC 2010

\begin{abstract}
Introduction Candida albicans and Candida glabrata are the two most common opportunistic pathogens which are part of the normal flora in humans. Clinical diagnosis of infection by these organisms is still largely based on culturing of these organisms. In order to identify species-specific protein expression patterns, we carried out a comparative proteomic analysis of $C$. albicans and C. glabrata.
\end{abstract}

Electronic supplementary material The online version of this article (doi:10.1007/s12014-010-9057-9) contains supplementary material, which is available to authorized users.

T. S. K. Prasad · S. Keerthikumar $\cdot$ R. Chaerkady •

K. Kandasamy $\cdot$ S. Renuse $\cdot$ A. Marimuthu $\cdot$ A. K. Venugopal $\cdot$

J. K. Thomas $\cdot$ H. K. C. Jacob $\cdot$ R. Goel $\cdot$ H. Pawar $\cdot$

N. A. Sahasrabuddhe $\cdot$ H. C. Harsha

Institute of Bioinformatics, International Technology Park,

Bangalore 560 066, India

S. Keerthikumar $\cdot$ K. Kandasamy $\cdot$ A. K. Venugopal $\cdot$ R. Goel $\cdot$

V. Krishna

Department of Biotechnology, Kuvempu University,

Shimoga, Karnataka 577 451, India

R. Chaerkady $\cdot$ K. Kandasamy $\cdot$ S. Renuse $\cdot$ A. K. Venugopal $\cdot$

H. K. C. Jacob $\cdot$ N. A. Sahasrabuddhe $\cdot$ A. Pandey $(\square)$

McKusick-Nathans Institute of Genetic Medicine and

Departments of Biological Chemistry, Pathology and Oncology,

Johns Hopkins University,

Baltimore, MD 21205, USA

e-mail: pandey@jhmi.edu

\section{S. Renuse $\cdot$ B. G. Nair}

Amrita School of Biotechnology, Amrita Vishwa Vidyapeetham,

Kollam, Kerala 690 525, India
Methods We used "isobaric tag for relative and absolute quantitation" (iTRAQ) labeling of cell homogenates of $C$. albicans and C. glabrata followed by LC-MS/MS analysis using a quadrupole time-of-flight mass spectrometer. The MS/MS data was searched against a protein database comprised of known and predicted proteins reported from these two organisms. Subsequently, we carried out a bioinformatics analysis to group orthologous proteins

A. Marimuthu $\cdot$ H. K. C. Jacob $\cdot$ N. A. Sahasrabuddhe $\cdot$

H. C. Harsha

Manipal University,

Manipal, Karnataka 576 104, India

H. Pawar

Rajiv Gandhi University of Health Sciences,

Bangalore, Karnataka 560 041, India

M. Gucek

Magnuson Clinical Center, National Institutes of Health,

National Heart, Lung, and Blood Institute,

8C103C,

Bethesda, MD 20892, USA

R. N. Cole

Institute of Basic Biomedical Sciences, Mass Spectrometry/

Proteomics Facility, Johns Hopkins University,

Baltimore, MD 21205, USA

\section{R. Ravikumar}

Department of Neuromicrobiology,

National Institute of Mental Health and Neuro Sciences,

Bangalore 560029, India 
across $C$. albicans and C. glabrata and calculated protein abundance changes between the two species.

Results and Conclusions We identified 500 proteins from these organisms, the large majority of which corresponded to predicted transcripts. A number of proteins were observed to be significantly differentially expressed between the two species including enolase (Eno1), fructose-bisphosphate aldolase (Fba1), CCT ring complex subunit (Cct2), pyruvate kinase (Cdc19), and pyruvate carboxylase (Pyc2). This study illustrates a strategy for investigating protein expression patterns across closely related organisms by combining orthology information with quantitative proteomics.

Keywords Biomarker $\cdot$ Candidiasis · Candidemia $\cdot$ Medical mycology $\cdot$ Molecular diagnostics $\cdot$ Fungal infection .

Quantitative proteomics

\section{Abbreviations \\ MTCC Microbial type culture collection \\ ORF Open reading frame}

\section{Introduction}

Candida albicans and Candida glabrata are the commonest opportunistic pathogens of human mucosa and blood [1-3]. Clinical disorders with immunosuppression including those with HIV and patients on chemotherapy provide an opportunity for the otherwise harmless C. glabrata to cause candidiasis. As a result, C. glabrata is now second to $C$. albicans among the various Candida species isolated from patients with candidiasis $[4,5]$. High prevalence of $C$. glabrata in the oral flora of patients with diabetes mellitus, advanced cancers, and HIV infection has been reported in several studies [6-11]. Often, high mortalities are associated with C. glabrata infections especially among cancer patients and bone marrow transplant patients [12-16]. The majority of C. glabrata isolates are reported to be resistant to both fluconazole and itraconazole [11], whereas most isolates of C. albicans are sensitive to these antifungal agents $[9,10]$. Thus, it is even more important to diagnose C. glabrata infections early and accurately so that the appropriate therapy can be initiated $[17,18]$.

Although C. albicans and C. glabrata are often coisolated from mucosal lesions, not many investigations have focused to study these organisms together. When together, they exhibit more severe symptoms and pose a greater difficulty in treatment $[19,20]$. Molecular diagnostic procedures described thus far to distinguish between these two species cannot easily be incorporated as routine diagnostics as they require specialized equipment and expertise [21-25]. Although these organisms cannot be distinguished based on the clinical presentation of the patients, they differ in many aspects of genetic and physiological attributes. C. albicans thrives as a diploid [26, 27] and exhibits considerable heterozygosity while $C$. glabrata exists as a haploid genome [28]. Unlike C. albicans, C. glabrata cannot form true hyphae [29]. C. glabrata does not produce extracellular proteinases including secreted aspartyl proteinases [30] which are considered as virulent factors of Candida species [31-35]. C. albicans lacking superoxide dismutases are unable to thrive in the presence of macrophages [36]. Phospholipases that have been implicated in the virulence of $C$. albicans [37-41] also do not seem to play a major role in C. glabrata infection [42, 43]. C. albicans and C. glabrata are also known to differ in their host response profiles. Infection by $C$. glabrata induces expression of high levels of granulocyte monocyte colony-stimulating factor in the cells of oral mucosa, while $C$. albicans is not known to elicit such a response. On the other hand, C. albicans infection produces a strong IL-8 response, whereas it is elicited only weakly in the case of $C$. glabrata-infected cells [44-46]. C. glabrata is often resistant to several antimicrobial proteins secreted by the host such as beta defensins [4749], histatins, and magainins [50-52]. A substantial variation among gene families involved in cell wall formation, transport, and sexual reproduction has been reported by comparing genomes of different pathogenic species of Candida and related yeasts [53]. Interestingly, a phylogenetic comparison of sequenced yeast genomes showed that $C$. glabrata belongs to "Saccharomyces clade" while most other Candida species including C. albicans belong to "Candida clade" [53]. The existence of distinct variation in diverse clinical features indicates the probable differences in the mechanisms of infection and adaptations to overcome host defense mechanisms and antifungal drugs. The availability of genome sequence information for both $C$. albicans [26] and C. glabrata [28] now provides a scaffold for proteomic investigations to understand distinct biological traits of these organisms at the molecular level. A comparative proteomic profile of $C$. albicans and C. glabrata should also provide information on differentially expressed proteins in these organisms that could serve as candidate molecules to distinguish these two species by protein-based tests such as ELISA. We describe a quantitative proteomic investigation using isobaric tag for relative and absolute quantitation (iTRAQ) reagents and mass spectrometry to identify the differentially expressed proteins in C. albicans and C. glabrata.

\section{Materials and Methods}

Culturing of C. albicans and C. glabrata

C. albicans (MTCC 1637) and C. glabrata (MTCC 6507) cultures were obtained from the Microbial Type Culture 
Collection \& Gene Bank resource in Chandigarh, India. The cells were cultured in identical conditions in $2 \%$ YPD broth at $30^{\circ} \mathrm{C}$ with shaking for $6 \mathrm{~h}$. The cells were harvested at the same density by centrifuging at $2,000 \times \mathrm{g}$ for $10 \mathrm{~min}$, and pellets were washed using sterile distilled water. Cell pellets were stored at $-80^{\circ} \mathrm{C}$ until further analysis.

iTRAQ Labeling and Strong Cation Exchange Fractionation

Cell pellets were dissolved in $0.5 \%$ SDS and homogenized. The samples were subsequently sonicated using ultrasonicator (Branson Ultrasonics) and centrifuged at $10,000 \times \mathrm{g}$ for $10 \mathrm{~min}$ at $4^{\circ} \mathrm{C}$. Clear supernatant was collected in fresh vials. Protein estimation was carried out using Lowry's assay. Further, two samples were normalized based on total protein amount. Normalization was verified by SDS-PAGE. Protein samples were reduced, cysteineblocked, and digested with trypsin. iTRAQ (Applied Biosystems Catalog No. 4352135) labeling of peptides was carried out according to manufacturer's protocol essentially as described earlier [54]. Briefly, $80 \mu \mathrm{g}$ of protein extract from each sample was treated with $2 \mu$ of reducing agent (tris(2-carboxyethyl) phosphine) at $60^{\circ} \mathrm{C}$ for $1 \mathrm{~h}$ and alkylated with $1 \mu \mathrm{l}$ of methyl methanethiosulfonate (MMTS)) for $10 \mathrm{~min}$ at room temperature. Proteins were then digested using sequencing grade trypsin (Promega) (1:10) overnight at $37^{\circ} \mathrm{C}$. Peptides in duplicate from $C$. albicans sample were labeled using iTRAQ reagents containing reporters 114 and 115 and peptides in duplicate from C. glabrata sample were labeled using iTRAQ reagents containing reporters 116 and 117 (Fig. 1). Labeling was carried out for $2 \mathrm{~h}$ at room temperature. After labeling, the peptides from the two samples were pooled and fractionated using strong cation exchange chromatography on Polysulfoethyl A column (PolyLC, Columbia, MD) $(100 \times 2.1 \mathrm{~mm}, 5 \mu \mathrm{m}$ particles with $300 \AA$ pores $)$ using an LC Packing HPLC system connected to a Probot fraction collector. Thirty SCX fractions were collected at a flow rate of $0.2 \mathrm{ml} / \mathrm{min}$ using a $70-\mathrm{min}$ gradient of $\mathrm{KCl}$ from 0 to $350 \mathrm{mM}$ concentration in $10 \mathrm{mM}$ potassium phosphate buffer, $25 \%$ acetonitrile ( $\mathrm{pH} 2.85$ ). The fractions were dried and reconstituted in $10 \mu \mathrm{l}$ of $2 \%$ trifluoroacetic acid before mass spectrometric analysis.

\section{Mass Spectrometry and Data Analysis}

Mass spectrometry analysis was carried out using a reversed-phase liquid chromatography system (RP-LC) interfaced with a quadrupole time-of-flight mass spectrometer (QSTAR/Pulsar, Applied Biosystems). MS/MS data was acquired by online analysis of peptides eluted using 5-

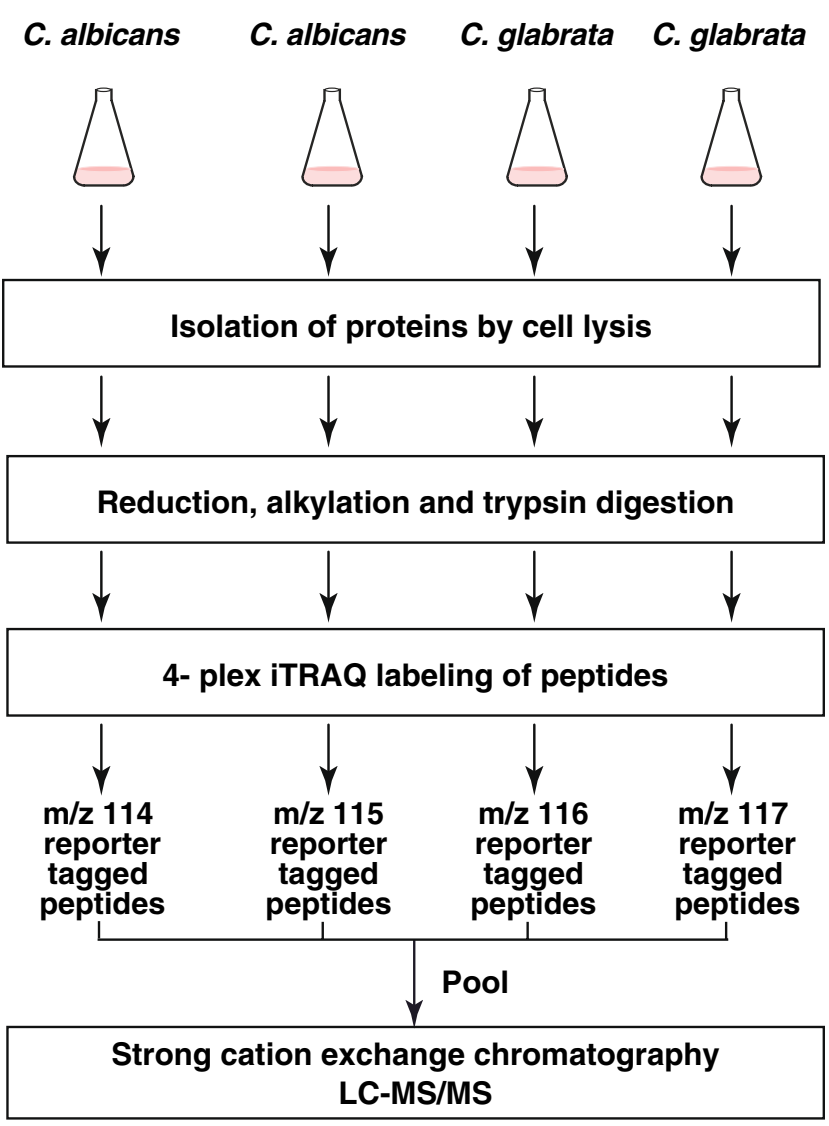

Fig. 1 A schematic of quantitative proteomic characterization of $C$. albicans and C. glabrata. After homogenization of cells, the proteins were digested with trypsin. The resulting peptides from $C$. albicans and C. glabrata were labeled with different iTRAQ reagents in a 4plex strategy and subsequently pooled. The peptide mixture was analyzed by LC-MS/MS, and the proteins were identified by searching the MS/MS spectra against the custom protein database and quantitated using intensities of reporter ions

$40 \%$ acetonitrile in $0.1 \%$ formic acid for 30 min with a flow rate of $300 \mathrm{nl} / \mathrm{min}$. The MS/MS spectra were acquired in a data-dependent manner from $\mathrm{m} / \mathrm{z} 350$ to 1,200 Da targeting three most abundant ions in every survey scan for MS/MS with a dynamic exclusion time of $45 \mathrm{~s}$. Twenty percent higher collision energy was applied during MS/MS scan with a charge state-dependent collision energy selection criteria.

We created a custom protein database of non-redundant protein sequences of $C$. albicans and $C$. glabrata by combining ORFs of $C$. albicans from the Candida Genome Database (http://candidagenome.org/), ORFs of C. glabrata from databases of Genolevures (http://genolevures.org/ download.html), and protein sequences of these organisms from NCBI RefSeq database. This customized database contained 39,196 protein sequences with 28,152 protein sequences from C. albicans and 11,044 from C. glabrata. We used ProteinPilot software (V 3.0 Applied Biosystems) for data analysis, which includes Paragon algorithm for 
A

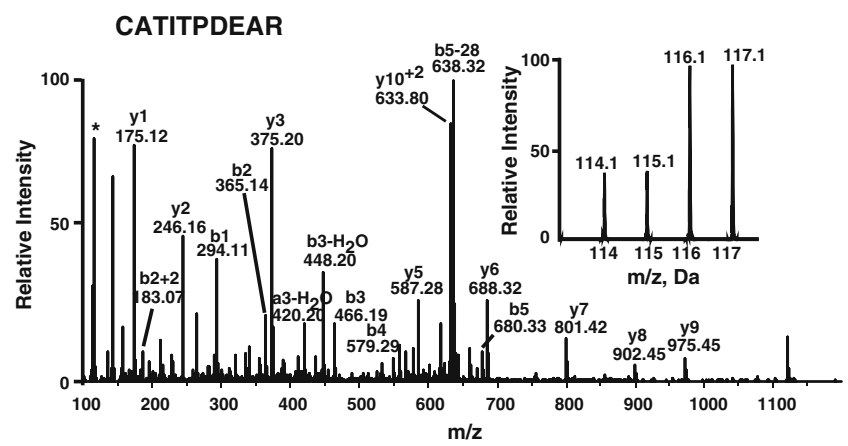

Cytosolic NADP-specific isocitrate dehydrogenase Idp2 (C. albicans)

Hypothetical protein CAGLOB04917g (C. glabrata)

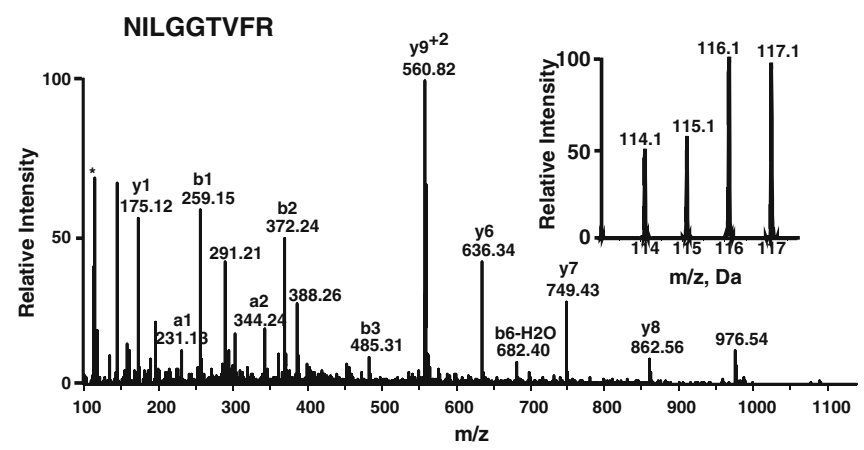

B

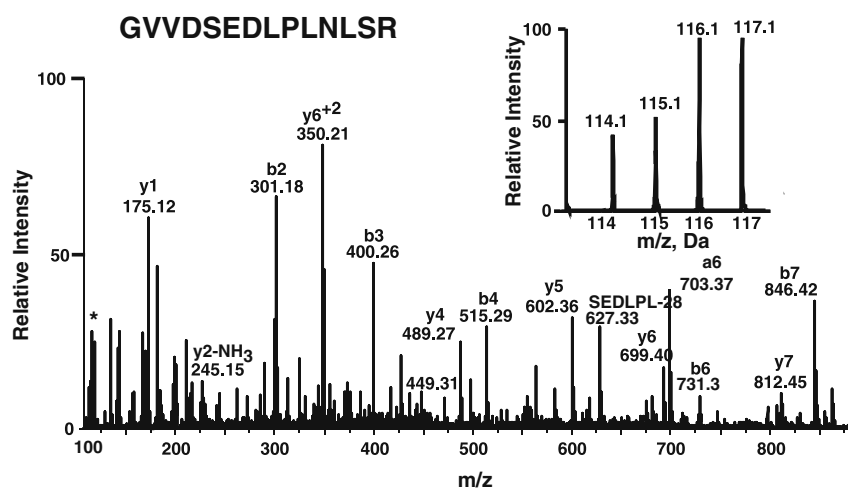

Heat shock protein Hsp90 (C. albicans) Hypothetical protein CAGLOL00495g (C. glabrata)

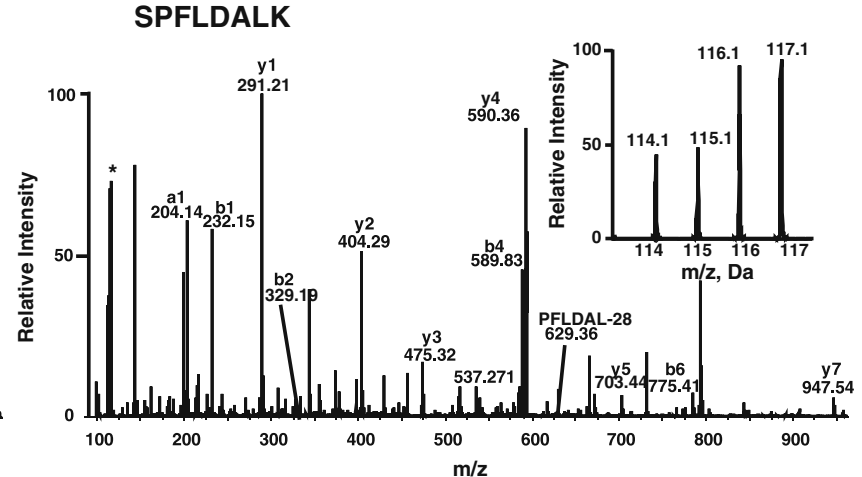

C

Enolase Eno1 (C. albicans)

Hypothetical protein CAGL0I02486g (C. glabrata)
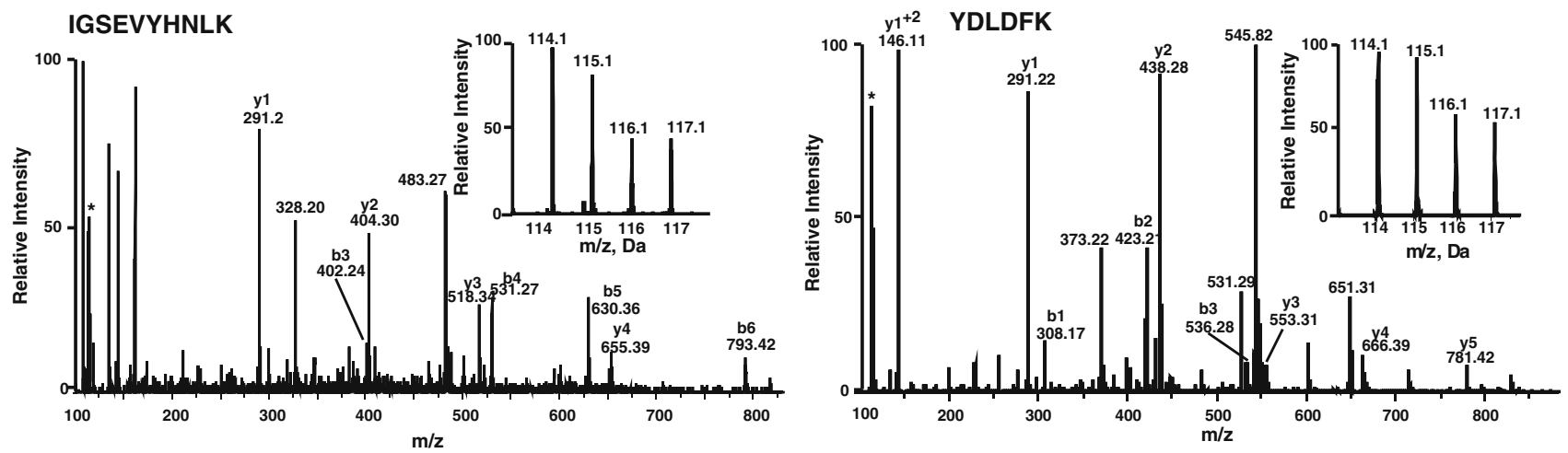

D

Pyruvate kinase Cdc19 (C. albicans]

Hypothetical protein CAGLOE05610g (C. glabrata)

GVNLPGTDVDLPALSEK

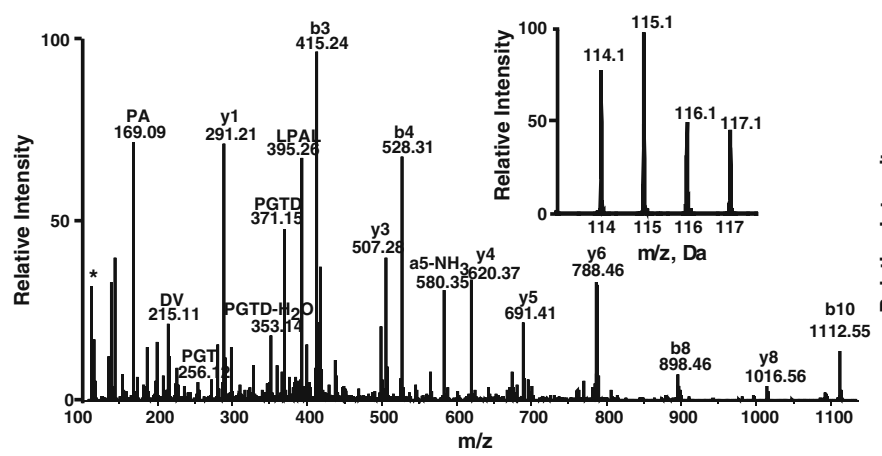

VHMIFASFIR

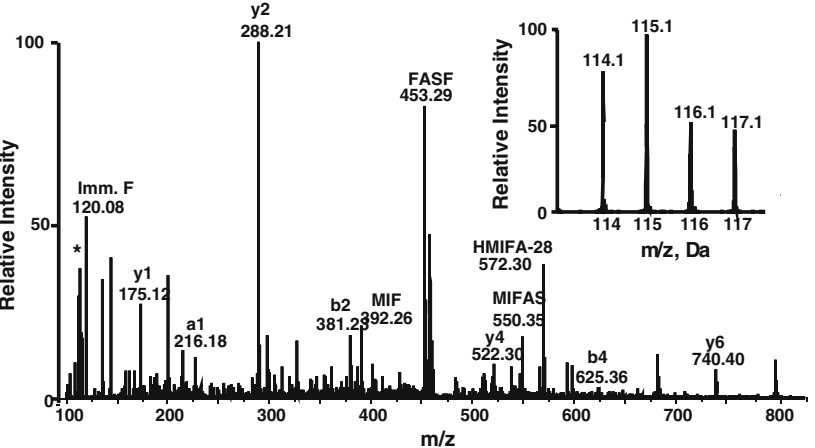

藻 Humana Press 
Fig. $2 \mathrm{MS} / \mathrm{MS}$ spectra of representative shared peptides from differentially expressed ortholog proteins. a Peptides CATITPDEAR and NILGGTVFR belonging to cytosolic NADP-specific isocitrate dehydrogenase Idp2 [C. albicans SC5314] and CAGL0B04917g [C. glabrata CBS138], expressed higher in C. glabrata. b Peptides GVVDSEDLPLNLSR and SPFLDALK belonging to heat shock protein Hsp90 [C. albicans SC5314] and hypothetical protein CAGL0L00495g [C. glabrata CBS138] expressed higher in $C$. glabrata. c Peptides IGSEVYHNLK and YDLDFK belonging to enolase Eno1 [C. albicans SC5314] and CAGL0I02486g [C. glabrata CBS138], expressed higher in C. albicans. d Peptides GVNLPGTDVDLPALSEK and VHMIFASFIR belonging to pyruvate kinase Cdc19 [C. albicans SC5314] and CAGL0E05610g [C. glabrata CBS138], expressed higher in C. albicans. (Insets) Relative intensity of reporter ions $(\mathrm{m} / \mathrm{z} ; \mathrm{C}$. albicans 114,115 and C. glabrata $116,117)$ from MS/MS fragmentation

peptide identification and Pro Group algorithm for summarizing proteins. Search parameters included iTRAQ labeling at $\mathrm{N}$-terminus and lysine residues, cysteine modification by MMTS as fixed modifications, and trypsin as a protease. Proteins identified with $>95 \%$ confidence or Protscore $>1.3$ as determined by Pro Group algorithm were used for further analysis. We used false discovery rate analysis by PSPEP software that is in-built into ProteinPilot 3.0. The data generated by LC-MS/MS analysis of $30 \mathrm{SCX}$ fractions were searched against the custom protein database, which includes protein sequences that belong to $C$. albicans and C. glabrata filtered from RefSeq, Candida Genome Database and ORF database of Genolvures using ProteinPilot 3.0 software. Peptides identified in this study are catalogued in Supplementary Table 1. A detected protein threshold of 1.3 which corresponds to a confidence of $95 \%$ was used in identification and quantitation of proteins.

\section{Results and Discussion}

In this study, we applied a quantitative proteomic approach to identify differentially expressed proteins in $C$. albicans and C. glabrata. Cell lysates of C. albicans and C. glabrata

\section{A \\ Phosphoglucose isomerase Pgl1 (C. albicans) DAMFAGDHINTTEDR}

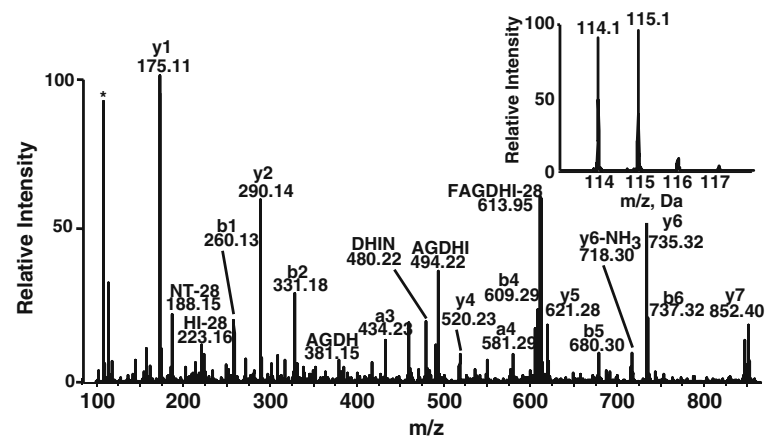

C

\section{Hypothetical protein CAGL0I06600g (C. glabrata) GLEPLGSVALR}

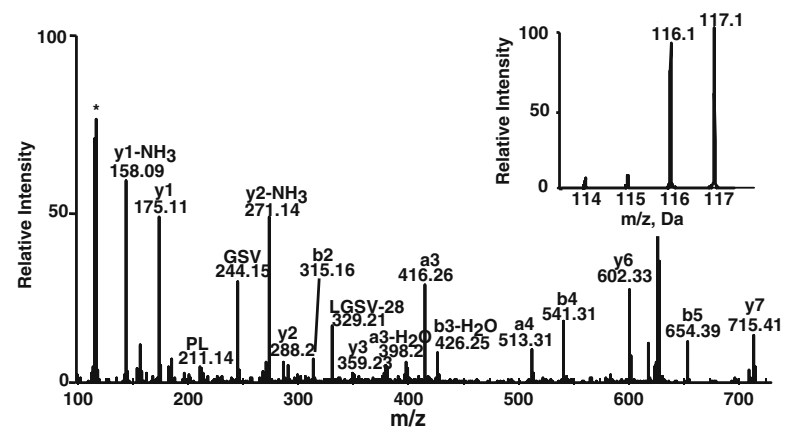

Fig. 3 Representative MS/MS spectra of peptides which are uniquely identified in either $C$. albicans or C. glabrata. a Peptide DAMFAGDHINTTEDR belongs to phosphoglucose isomerase Pgl1. b Peptide AVVFDTNGGQLVYK belongs to immunogenic alcohol dehydrogenase Adh1 of $C$. albicans. c Peptide GLEPLGSVALR
B

Immunogenic alcohol dehydrogenase Adh1 (C. albicans) AVVFDTNGGQLVYK

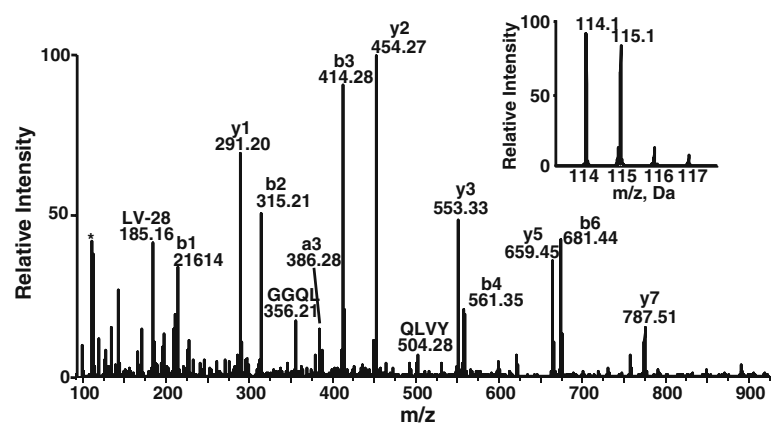

D
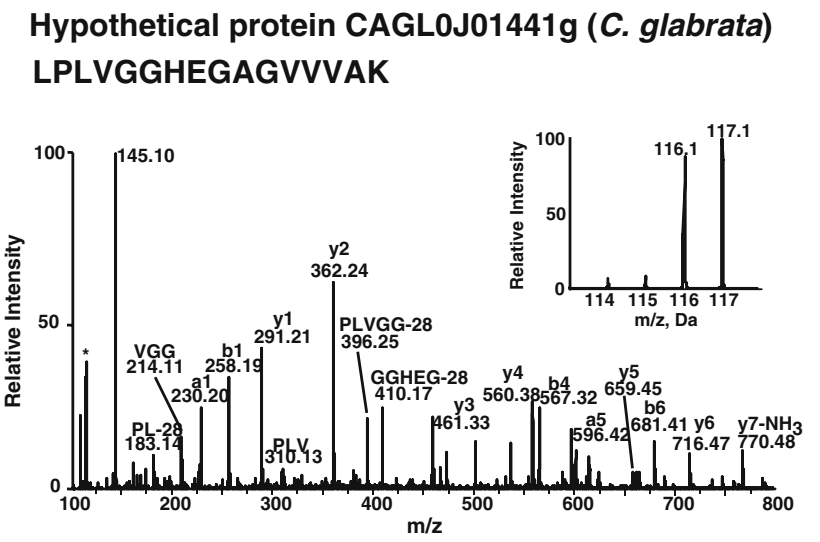

belongs to hypothetical proteins CAGL0I06600g. d Peptide LPLVGGHEGAGVVVAK belongs to CAGL0J01441g of C. glabrata. (Insets) Relative intensity of reporter ions $(\mathrm{m} / \mathrm{z} ; \mathrm{C}$. albicans 114, 115 and C. glabrata 116, 117) from MS/MS fragmentation 
were labeled with iTRAQ reagents as shown in Fig. 1. We prepared technical replicates by labeling peptides derived from $C$. albicans with iTRAQ reagents giving rise to reporter ions at $\mathrm{m} / \mathrm{z}$ of 114 and 115 and $C$. glabrata derived peptides with those yielding reporter ions at $\mathrm{m} / \mathrm{z}$ of 116 and 117. From a total of $24,196 \mathrm{MS} / \mathrm{MS}$ spectra, using a ProtScore $>1.3$ (95\% confidence) cutoff, we identified 500 proteins among these organisms, 386 of which belonged to

Table 1 A partial list of proteins differentially expressed in Candida albicans

\begin{tabular}{|c|c|c|c|c|c|}
\hline & $\begin{array}{l}\text { Gene } \\
\text { IDs }\end{array}$ & Protein name & $\begin{array}{l}\text { Relative expression } \\
\text { (C. glabratal } \\
\text { C. albicans) }\end{array}$ & $\begin{array}{l}\text { Common tryptic peptides } \\
\text { ( } \leq 95 \% \text { confidence) }\end{array}$ & $\begin{array}{l}\text { Common tryptic peptides } \\
\text { ( } \geq 95 \% \text { confidence) }\end{array}$ \\
\hline 1 & $\begin{array}{l}3643055 \\
2886326\end{array}$ & $\begin{array}{l}\text { Translation elongation factor } \\
\text { Eft2 [C. albicans }] \\
\text { Hypothetical protein } \\
\text { CAGL0A03234g } \\
\text { [C. glabrata }]\end{array}$ & 0.39 & $\begin{array}{l}\text { MVPTSDK, NMSVIAHVDHGK, } \\
\text { AYLPVNESFGFTGELR, } \\
\text { AVQYLNEIK, AGIISAAK }\end{array}$ & $\begin{array}{l}\text { KFGVDK, KIWCFGPDGNGPNLVVDQTK, } \\
\text { FYAFGRVFAGTVK }\end{array}$ \\
\hline 2 & $\begin{array}{l}3646484 \\
2889384\end{array}$ & $\begin{array}{l}\text { Enolase Eno1 }[\text { C. albicans }] \\
\text { Hypothetical protein } \\
\text { CAGL0I02486g } \\
{[\text { C. glabrata }]}\end{array}$ & 0.42 & DGKYDLDFK, IGSEVYHNLK & YDLDFK \\
\hline 3 & $\begin{array}{l}3643438 \\
2887537\end{array}$ & $\begin{array}{l}\text { Pyruvate kinase Cdc } 19 \\
{[\text { C. albicans }]} \\
\text { Hypothetical protein } \\
\text { CAGL0E } 05610 \mathrm{~g} \\
{[\text { C. glabrata }]}\end{array}$ & 0.50 & $\begin{array}{l}\text { GVNLPGTDVDLPALSEK, } \\
\text { VHMIFASFIR, GRPLAIALDTK, } \\
\text { AEVSDVGNAILDGADCVMLSGETAK }\end{array}$ & - \\
\hline 4 & 2890854 & $\begin{array}{l}\text { Fructose-bisphosphate } \\
\text { aldolase Fba1 } \\
\text { [C. albicans }] \\
\text { Hypothetical protein } \\
\text { CAGL0L02497g } \\
\text { [C. glabrata }]\end{array}$ & 0.18 & VNLDTDCQYAYLTGIR & - \\
\hline 5 & 3635345 & $\begin{array}{l}\text { Fatty acid synthase alpha } \\
\text { subunit } \mathrm{CaO} 19.13370 \\
{[\text { C. albicans] }} \\
\text { Hypothetical protein } \\
\text { CAGL0E06138g } \\
\text { [C. glabrata] }\end{array}$ & 0.62 & AVSVTSFGFGQK & - \\
\hline 6 & 2889732 & $\begin{array}{l}\text { Likely cytosolic ribosomal } \\
\text { protein Rps } 24 \\
{[\text { C. albicans] }} \\
\text { Hypothetical protein } \\
\text { CAGL0J03234g } \\
\text { [C. glabrata] }\end{array}$ & 0.47 & ANVSKDELR, DAVSVFGFR & - \\
\hline 7 & 2891198 & $\begin{array}{l}\text { Cytoplasmic threonyl-tRNA } \\
\text { synthetase Ths1 } \\
\text { (Cao19.5685) } \\
\text { [C. albicans] } \\
\text { Hypothetical protein } \\
\text { CAGL0M12991g } \\
\text { [C. glabrata }]\end{array}$ & 0.64 & VADFGVIHR & VADFGVIHRNEFSGALSGLTRVR \\
\hline 8 & 2889320 & $\begin{array}{l}\text { RAN-like GTP binding } \\
\text { protein Gsp1 } \\
{[\text { C. albicans }]} \\
\text { Hypothetical protein } \\
\text { CAGL0I00594g } \\
\text { [C. glabrata] }\end{array}$ & 0.74 & $\begin{array}{l}\text { VCENIPIVLCGNK, NLQYYDISAK, } \\
\text { LVLVGDGGTGK, FDVWDTAGQEK }\end{array}$ & - \\
\hline 9 & $\begin{array}{l}3645696 \\
2890073\end{array}$ & $\begin{array}{l}\text { Histone H2B Htb1 } \\
{[\text { C. albicans }]} \\
\text { Hypothetical protein } \\
\text { CAGL0K11462g } \\
\text { [C. glabrata] }\end{array}$ & 0.46 & $\begin{array}{l}\text { LILPGELAK, AMSIMNSFVNDIFER, } \\
\text { QTHPDTGISQK }\end{array}$ & - \\
\hline 10 & 2886651 & $\begin{array}{l}\text { Dihydroxyacid dehydratase } \\
\text { Ilv3 (cao19.4040) } \\
\text { [C. albicans] } \\
\text { Hypothetical protein } \\
\text { CAGL0B03993g } \\
\text { [C. glabrata }]\end{array}$ & 0.42 & $\begin{array}{l}\text { GGPGMPEMLKPSSALMGYGLGK, } \\
\text { DVALLTDGR }\end{array}$ & \\
\hline
\end{tabular}


C. albicans and 114 proteins belonged to C. glabrata (Supplementary Tables 2 and 3). As tryptic peptide profile was different for individual proteins among protein homolog pairs of these two species, the ProteinPilot 3.0 software could not cluster most of protein orthologs as "pairs". In this study, it clustered only 24 protein orthologs among the 500 identified proteins belonging to both species. Thus, quantitation data determined by the ProteinPilot 3.0 software were biologically relevant for only these 24 ortholog proteins. Therefore, we performed in-house bioinformatics analysis to determine protein pairs and their relative expression levels based on the relative expression profile of common tryptic peptides as follows. For each protein identified, we determined its counterpart in other species under investigation using a reciprocal BLAST analysis. We identified another set of 35 ortholog proteins in addition to 24 ortholog proteins clustered by ProteinPilot 3.0. At least one common tryptic peptide was observed for these 59 ortholog pairs identified in this study. We calculated weighted average ratio for relative expression level of peptides for these 59 protein pairs using the formula used by ProteinPilot 3.0 software. The values of reporter ion ratio 115:114 for all of these protein pairs were found to be near 1 as expected with an average of $1.05 \pm$

Table 2 A partial list of proteins with higher levels of expression in Candida glabrata

\begin{tabular}{|c|c|c|c|c|c|}
\hline & $\begin{array}{l}\text { Gene } \\
\text { IDs }\end{array}$ & Protein name & $\begin{array}{l}\text { Relative expression } \\
\text { (C. glabratal } \\
\text { C. albicans) }\end{array}$ & $\begin{array}{l}\text { Common tryptic peptides } \\
\text { ( } \leq 95 \% \text { confidence) }\end{array}$ & $\begin{array}{l}\text { Common tryptic peptides } \\
(\geq 95 \% \text { confidence })\end{array}$ \\
\hline 1 & $\begin{array}{l}3640000 \\
2889085\end{array}$ & $\begin{array}{l}\text { Likely cobalamin-independent } \\
\text { methionine synthase Met6 } \\
{[\text { C. albicans }]} \\
\text { Hypothetical protein } \\
\text { CAGL0I04994g [C. glabrata }]\end{array}$ & 1.51 & $\begin{array}{l}\text { ALDADVVSIEFSK, } \\
\text { FWVNPDCGLK }\end{array}$ & - \\
\hline 2 & $\begin{array}{l}3641547 \\
2890901\end{array}$ & $\begin{array}{l}\text { Likely adenylylsulfate kinase } \\
\text { Met14 [C. albicans }] \\
\text { Hypothetical protein } \\
\text { CAGL0L02321g }[\text { C. glabrata }]\end{array}$ & 1.53 & DLGFSEADRNENIR & - \\
\hline 3 & $\begin{array}{l}3640659 \\
2886465\end{array}$ & $\begin{array}{l}\text { Adenosine triphosphatase Pma1 } \\
\text { [C. albicans }] \\
\text { Hypothetical protein } \\
\text { CAGL0A00495g }[\text { C. glabrata }]\end{array}$ & 1.54 & $\begin{array}{l}\text { GYLVAMTGDGVNDAPSLK, } \\
\text { SAADIVFLAPGLSAIIDALK, } \\
\text { GAPLFVLK, KQAIVQK }\end{array}$ & KGLDAIDK \\
\hline 4 & $\begin{array}{l}3642461 \\
2887298\end{array}$ & $\begin{array}{l}\text { Likely } 26 \text { S proteasome regulatory } \\
\text { particle ATPase Rpt1 [C. albicans }] \\
\text { Hypothetical protein } \\
\text { CAGL0E06490g }[\text { C. glabrata }]\end{array}$ & 1.57 & KVEFSLPDLEGR & $\begin{array}{l}\text { VIGSELVQKYVGEGAR, } \\
\text { YVGEGARMVRELFEMAR }\end{array}$ \\
\hline 5 & $\begin{array}{l}3644290 \\
2886604\end{array}$ & $\begin{array}{l}\text { Mitochondrial ketol-acid reductoi } \\
\text { somerase Ilv5 [C. albicans }] \\
\text { Hypothetical protein } \\
\text { CAGL0B03047g }[\text { C. glabrata }]\end{array}$ & 1.60 & $\begin{array}{l}\text { TLYFSHGFSPVFK, } \\
\text { DNGLNVIIGVR, } \\
\text { YGMDYMYDACSTTAR }\end{array}$ & - \\
\hline 6 & $\begin{array}{l}3647367 \\
2886846\end{array}$ & $\begin{array}{l}\text { Histone } \mathrm{H} 3 \mathrm{Hht} 2[\text { C. albicans }] \\
\text { Hypothetical protein } \\
\text { CAGL0M06655g }[\text { C. glabrata }]\end{array}$ & 1.72 & KSAPSTGGVK, YKPGTVALR & $\begin{array}{l}\text { QTARKSTGGK, KSTGGK, } \\
\text { STGGKAPR, KQLASK, } \\
\text { KLPFQR }\end{array}$ \\
\hline 7 & $\begin{array}{l}3637507 \\
2891108\end{array}$ & $\begin{array}{l}\text { Heat shock protein Hsp } 90 \\
{[\text { C. albicans }]} \\
\text { Hypothetical protein } \\
\text { CAGL0L00495g }[\text { C. glabrata }]\end{array}$ & 2.10 & $\begin{array}{l}\text { GVVDSEDLPLNLSR, } \\
\text { SPFLDALK }\end{array}$ & $\begin{array}{l}\text { EDQLEYLEEK, TKPLWTR, } \\
\text { KNNIK }\end{array}$ \\
\hline 8 & $\begin{array}{l}3644934 \\
2886496\end{array}$ & $\begin{array}{l}\text { Cytosolic NADP-specific isocitrate } \\
\text { dehydrogenase Idp2 [C. albicans }] \\
\text { Hypothetical protein } \\
\text { CAGL0B04917g [C. glabrata }]\end{array}$ & 2.24 & $\begin{array}{l}\text { NILGGTVFR, CATITPDEAR, } \\
\text { LIDDMVAQMLK }\end{array}$ & - \\
\hline 9 & 2887212 & $\begin{array}{l}\text { Mitochondrial NADP-specific } \\
\text { isocitrate dehydrogenase Idp1 } \\
{[\text { C. albicans }]} \\
\text { Hypothetical protein } \\
\text { CAGL0D00770g [C. glabrata }]\end{array}$ & 2.36 & CATITPDEAR, NILGGTVFR & - \\
\hline 10 & $\begin{array}{l}3639407 \\
2890421\end{array}$ & $\begin{array}{l}\text { Beta-tubulin Tub2 [C. albicans }] \\
\text { Hypothetical protein } \\
\text { CAGL0K12650g }[\text { C. glabrata }]\end{array}$ & 2.44 & $\begin{array}{l}\text { KLAVNLVPFPR, } \\
\text { LAVNLVPFPR }\end{array}$ & - \\
\hline
\end{tabular}


0.08. Also, values of (116:114)/(117:114) were also expected to be near 1 and found with an average of $0.93 \pm 0.1$. MS/MS spectra of representative peptides belonging to four differentially expressed protein pairs are given in Fig. 2. The relative intensities of reporter ions from these spectra are shown in the insets. As shown in the Fig. 2, reporter ion intensities of individual common peptides belonging to same ortholog protein pairs were found to be in agreement with each other. Intensities of these reporter ions among technical replicates were also found to be in the same range. The mass spectrometry data generated in this study has been submitted to Peptidome resource (http://www.ncbi.nlm.nih.gov/pepdome).

Substantial differences exist between the genomes and proteomes of $C$. albicans and C. glabrata, which influences protein identification in these two species. C. albicans is diploid with considerable heterozygosity, whereas C. glabrata thrives as a simple haploid. C. albicans has 12,015 genes encoded by its heterozygous diploid genome including alleles as described by genome sequencing consortium [26, 27], whereas C. glabrata has only over 5,000 genes as described by Dujon et al. [28]. It was also observed that the proteome diversity of $C$. albicans is further enhanced by ambiguous usage of CUG codon to randomly incorporate either amino acid leucine or serine in the proteome, whereas such codon alternation is not reported in C. glabrata [55-57].

This protein pair analysis identified several proteins which are expressed only in either $C$. albicans or C. glabrata. MS/ MS spectra of these peptides showed only reporter ions belonging to either C. albicans or C. glabrata (Fig. 3). Proteins which are found to be expressed only in $C$. albicans included 3-phosphoglycerate kinase (Pgk1), pyruvate decarboxylase (CaO19.2877), immunogenic alcohol dehydrogenase (Adh1), and heat shock protein 60 (Hsp60). It is interesting to note that several proteins involved in glucose metabolism including gluconeogenesis are highly expressed in C. albicans. There is also a marked difference in the expression of serine-, lysyl-, leucyl-, and valyl-tRNA synthetases and several ribosomal subunits, which is significant in the context of differential usage of specific codons in C. albicans or $C$. glabrata [53]. Proteins expressed unique to C. glabrata included hypothetical proteins CAGL0I06600g (similar to ubiquitin-specific proteinase Ubp3), CAGL0I01496g (similar to heat shock protein Ssc1), CAGL0E03916g (similar to glycerol kinase Gut1), and CAGL0L12364g (similar to acetyl-CoA C-acetyltransferaseYPL028w).

Analysis of expression levels of orthologous proteins showed that 19 proteins of $C$. albicans were found to be higher ( $>1.5$-fold) in abundance when compared to their corresponding orthologs in C. glabrata (Table 1). Conversely, expression levels of 12 C. glabrata proteins were found to be higher when compared to their counterparts in C. albicans (Table 2). The relative protein expression ratios (i.e., 116:114 or 117:114) for the remaining 28 protein pairs ranged from 0.75 to 1.5 (Fig. 4). Proteins with higher expression levels in C. albicans included enolase (Eno1), fructose-bisphosphate aldolase (Fba1), dihydroxyacid dehydratase (Ilv3), glutathione oxidoreductase (Glr1), ubiquitin-activating enzyme (Uba1), and chaperonin CCT ring complex subunit (Cct2). Interestingly, fructose-bisphosphate aldolase has already been investigated as a target in C. albicans using a methionine/ cysteine-conditional mutant [58]. Proteins expressed higher in C. glabrata include several hypothetical proteins CAGL0F06941g (similar to pyruvate carboxylase fragment Pyc2), CAGL0L00495g (similar to heat shock protein Hsp90), CAGL0A00495g (similar to adenosine triphosphatase Pma1), CAGL0L02321g (likely adenylylsulfate kinase Met14), CAGL0B04917g (similar to cytosolic NADP-specific isoci-

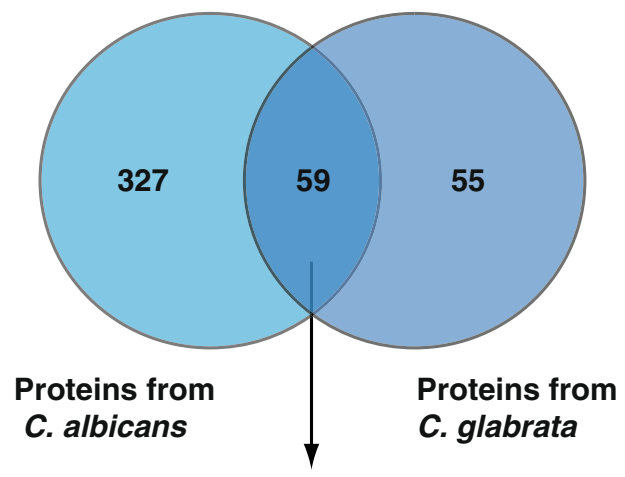

Protein pairs from C. albicans and C. glabrata which share tryptic peptides
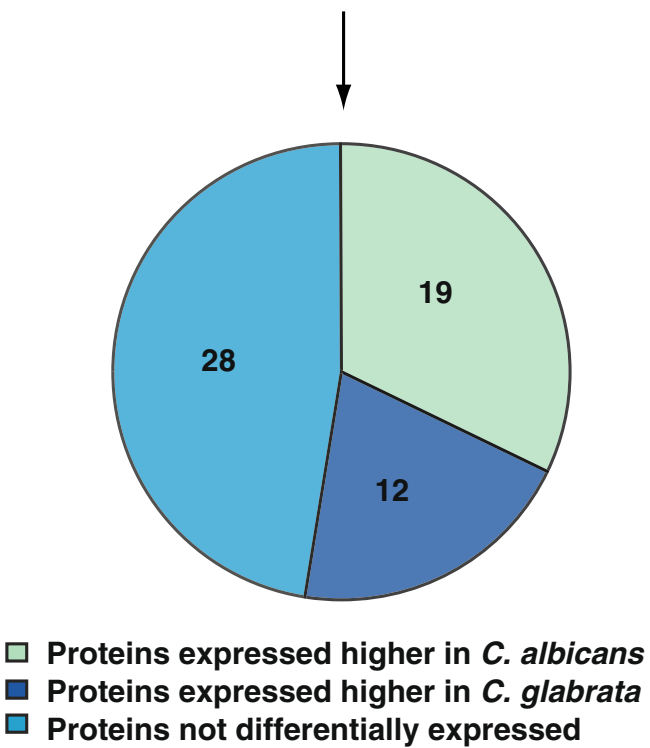

Fig. 4 Proteins identified in C. albicans and C. glabrata. (Venn diagram) Out of 500 proteins identified, shared tryptic peptides were obtained for 59 protein orthologs. (Pie diagram) Based on relative intensities of these shared peptides, abundances of these proteins between two organisms were calculated. Out of 59 ortholog proteins, 19 were more abundant in C. albicans and 12 in C. glabrata 
trate dehydrogenase Idp2), and CAGL0D00770g (similar to mitochondrial NADP-specific isocitrate dehydrogenase Idp1). Overexpression of Hsp90 in C. glabrata is interesting in the light of its established role in the emergence of azole drug resistance. It was shown that loss of Hsp90 function in yeast and $C$. albicans resulted in the decreased resistance to antifungal drugs including echinocandins $[59,60]$.

The peptides/proteins which are unique to one organism and/or differentially expressed between two organisms should be attractive candidates as potential biomarkers for the diagnosis and monitoring of treatment. Development of similar rapid diagnostic methods have been investigated in order to identify infections by Plasmodium falciparum, Plasmodium vivax, Plasmodium ovale, and Plasmodium malariae using antibodies generated against merozoite surface protein 1 , which are highly expressed among these pathogens [61, 62]. Similarly, histidine-rich protein-2 (HRP-2) of P. falciparum and lactate dehydrogenase ( $\mathrm{Pv}-$ pLDH) of $P$. vivax have been targeted in the FK80 kit (Standard Diagnostics, Korea) to differentially diagnose malaria infection caused by $P$. falciparum and $P$. vivax [63]. Another successful attempt has been the development of ELISA-based antigen capture assays targeting nonstructural protein (NS1) for laboratory detection of acute primary and secondary dengue [61, 64, 65]. Our study provides a list of proteins which are uniquely or differentially expressed in C. albicans and C. glabrata which can be used in the development of such diagnostic tests. This study also demonstrates a comparative proteomics platform which will facilitate the discovery of several such candidate target molecules with diagnostic potential in many other human diseases with multiple etiologies.

\section{Conclusions}

Generally, quantitative proteomic studies are carried out to compare the proteomes of the same species under more than one condition. Often, there is a need to compare two distinct but related proteomes. The orthology-based approach has been used to profile proteomes of organisms with unsequenced genomes [66], but not for differential profiling of proteomes between two closely related organisms. Our study outlines a strategy to investigate protein expression patterns across closely related organisms, by combining orthology information with quantitative proteomics. Such studies should help identify mechanisms responsible for distinct biological features of clinical importance among closely related organisms as exemplified in $C$. albicans and $C$. glabrata. As discussed previously, although C. albicans and C. glabrata cause similar infections, they exhibit distinct biological features. As most proteins from C. albicans and $C$. glabrata are yet to be investigated in detail for their role in various biological processes, our study provides the basis to guide such investigations in the future.

Acknowledgements We thank the Department of Biotechnology of the Government of India for research support to the Institute of Bioinformatics, Bangalore. TSKP is supported by research grants including a Young Investigator award from the Department of Biotechnology, India. We thank the Council for Scientific and Industrial Research (CSIR), India for the research support to HKCJ, HP, and NP and the University Grants Commission (UGC), India for the research support to SR.

Conflict of Interest The authors have declared no conflict of interest.

\section{References}

1. Pfaller MA, Diekema DJ. Rare and emerging opportunistic fungal pathogens: concern for resistance beyond Candida albicans and Aspergillus fumigatus. J Clin Microbiol. 2004;42(10):4419-31.

2. Vazquez JA. Options for the management of mucosal candidiasis in patients with AIDS and HIV infection. Pharmacotherapy. 1999;19(1):76-87.

3. Pfaller MA. Nosocomial candidiasis: emerging species, reservoirs, and modes of transmission. Clin Infect Dis. 1996;22 Suppl 2:S89-94.

4. Wingard JR. Importance of Candida species other than Candida albicans as pathogens in oncology patients. Clin Infect Dis. 1995;20(1):115-25.

5. Fidel Jr PL, Vazquez JA, Sobel JD. Candida glabrata: review of epidemiology, pathogenesis, and clinical disease with comparison to C. albicans. Clin Microbiol Rev. 1999;12(1):80-96.

6. Kadir T, Pisiriciler R, Akyuz S, Yarat A, Emekli N, Ipbuker A. Mycological and cytological examination of oral candidal carriage in diabetic patients and non-diabetic control subjects: thorough analysis of local aetiologic and systemic factors. J Oral Rehabil. 2002;29(5):452-7.

7. Canuto MM, Rodero FG, Ducasse VOD, et al. Determinants for the development of oropharyngeal colonization or infection by fluconazole-resistant Candida strains in HIV-infected patients. Eur J Clin Microbiol Infect Dis. 2000;19(8):593-601.

8. Fongsmut T, Deerochanawong C, Prachyabrued W. Intraoral Candida in Thai diabetes patients. J Med Assoc Thai. 1998;81 (6):449-53.

9. Redding SW, Kirkpatrick WR, Coco BJ, et al. Candida glabrata oropharyngeal candidiasis in patients receiving radiation treatment for head and neck cancer. J Clin Microbiol. 2002;40(5):1879-81.

10. Redding SW, Dahiya MC, Kirkpatrick WR, et al. Candida glabrata is an emerging cause of oropharyngeal candidiasis in patients receiving radiation for head and neck cancer. Oral Surg Oral Med Oral Pathol Oral Radiol Endo. 2004;97(1):47-52.

11. Bagg J, Sweeney MP, Lewis MA, et al. High prevalence of nonalbicans yeasts and detection of anti-fungal resistance in the oral flora of patients with advanced cancer. Palliat Med. 2003;17 (6):477-81.

12. Clark TA, Hajjeh RA. Recent trends in the epidemiology of invasive mycoses. Curr Opin Infect Dis. 2002;15(6):569-74.

13. Anaissie EJ, Vartivarian SE, Abi-Said D, et al. Fluconazole versus amphotericin B in the treatment of hematogenous candidiasis: a matched cohort study. Am J Med. 1996;101(2):170-6.

14. Goodman JL, Winston DJ, Greenfield RA, et al. A controlled trial of fluconazole to prevent fungal infections in patients undergoing bone marrow transplantation. N Engl J Med. 1992;326(13):84551. 
15. Krcmery Jr V, Oravcova E, Spanik S, et al. Nosocomial breakthrough fungaemia during antifungal prophylaxis or empirical antifungal therapy in 41 cancer patients receiving antineoplastic chemotherapy: analysis of aetiology risk factors and outcome. J Antimicrob Chemother. 1998;41(3):373-80.

16. Hajjeh RA, Sofair AN, Harrison LH, et al. Incidence of bloodstream infections due to Candida species and in vitro susceptibilities of isolates collected from 1998 to 2000 in a population-based active surveillance program. J Clin Microbiol. 2004;42(4):1519-27.

17. Willocks L, Leen CL, Brettle RP, Urquhart D, Russell TB, Milne LJ. Fluconazole resistance in AIDS patients. J Antimicrob Chemother. 1991;28(6):937-9.

18. Hitchcock CA, Pye GW, Troke PF, Johnson EM, Warnock DW. Fluconazole resistance in Candida glabrata. Antimicrob Agents Chemother. 1993;37(9):1962-5.

19. Redding SW, Zellars RC, Kirkpatrick WR, et al. Epidemiology of oropharyngeal Candida colonization and infection in patients receiving radiation for head and neck cancer. J Clin Microbiol. 1999;37(12):3896-900.

20. Redding SW. The role of yeasts other than Candida albicans in oropharyngeal candidiasis. Curr Opin Infect Dis. 2001;14(6):6737.

21. Panackal AA, Gribskov JL, Staab JF, Kirby KA, Rinaldi M, Marr KA. Clinical significance of azole antifungal drug cross-resistance in Candida glabrata. J Clin Microbiol. 2006;44(5):1740-3.

22. Valerio HM, Weikert-Oliveira Rde C, Resende MA. Differentiation of Candida species obtained from nosocomial candidemia using RAPD-PCR technique. Rev Soc Bras Med Trop. 2006;39 (2):174-8.

23. Santos MA, el-Adlouni C, Cox AD, Luz JM, Keith G, Tuite MF. Transfer RNA profiling: a new method for the identification of pathogenic Candida species. Yeast. 1994;10(5):625-36.

24. Essendoubi M, Toubas D, Bouzaggou M, Pinon JM, Manfait M, Sockalingum GD. Rapid identification of Candida species by FTIR microspectroscopy. Biochim Biophys Acta. 2005;1724(3):23947.

25. Gupta N, Haque A, Lattif AA, Narayan RP, Mukhopadhyay G, Prasad R. Epidemiology and molecular typing of Candida isolates from burn patients. Mycopathologia. 2004;158(4):397-405.

26. Jones T, Federspiel NA, Chibana $\mathrm{H}$, et al. The diploid genome sequence of Candida albicans. Proc Natl Acad Sci USA. 2004;101(19):7329-34.

27. van het Hoog M, Rast TJ, Martchenko M, et al. Assembly of the Candida albicans genome into sixteen supercontigs aligned on the eight chromosomes. Genome Biol. 2007;8(4):R52.

28. Dujon B, Sherman D, Fischer G, et al. Genome evolution in yeasts. Nature. 2004;430(6995):35-44.

29. Lachke SA, Joly S, Daniels K, Soll DR. Phenotypic switching and filamentation in Candida glabrata. Microbiology. 2002;148(Pt 9):2661-74

30. Chakrabarti A, Nayak N, Talwar P. In vitro proteinase production by Candida species. Mycopathologia. 1991;114(3):163-8.

31. Magee BB, Hube B, Wright RJ, Sullivan PJ, Magee PT. The genes encoding the secreted aspartyl proteinases of Candida albicans constitute a family with at least three members. Infect Immun. 1993;61(8):3240-3.

32. Monod M, Togni G, Hube B, Sanglard D. Multiplicity of genes encoding secreted aspartic proteinases in Candida species. Mol Microbiol. 1994;13(2):357-68.

33. Gilfillan GD, Sullivan DJ, Haynes K, Parkinson T, Coleman DC, Gow NA. Candida dubliniensis: phylogeny and putative virulence factors. Microbiology. 1998;144(Pt 4):829-38.

34. Zaugg C, Borg-Von Zepelin M, Reichard U, Sanglard D, Monod M. Secreted aspartic proteinase family of Candida tropicalis. Infect Immun. 2001;69(1):405-12.
35. Hube B, Naglik J. Candida albicans proteinases: resolving the mystery of a gene family. Microbiology. 2001;147(Pt 8):19972005.

36. Frohner IE, Bourgeois C, Yatsyk K, Majer O, Kuchler K. Candida albicans cell surface superoxide dismutases degrade host-derived reactive oxygen species to escape innate immune surveillance. Mol Microbiol. 2009;71(1):240-52.

37. Barrett-Bee K, Hayes Y, Wilson RG, Ryley JF. A comparison of phospholipase activity, cellular adherence and pathogenicity of yeasts. J Gen Microbiol. 1985;131(5):1217-21.

38. Banno Y, Yamada T, Nozawa Y. Secreted phospholipases of the dimorphic fungus, Candida albicans; separation of three enzymes and some biological properties. Sabouraudia. 1985;23(1):47-54.

39. Cole GT, Lynn KT, Seshan KR. An animal model for oropharyngeal, esophageal and gastric candidosis. Mycoses. 1990;33(1):719 .

40. Ibrahim AS, Mirbod F, Filler SG, et al. Evidence implicating phospholipase as a virulence factor of Candida albicans. Infect Immun. 1995;63(5):1993-8.

41. Takahashi M, Banno Y, Nozawa Y. Secreted Candida albicans phospholipases: purification and characterization of two forms of lysophospholipase-transacylase. J Med Vet Mycol. 1991;29 (3):193-204.

42. Samaranayake YH, MacFarlane TW, Samaranayake LP, Aitchison $\mathrm{T}$. The in vitro proteolytic and saccharolytic activity of Candida species cultured in human saliva. Oral Microbiol Immunol. 1994;9(4):229-35.

43. Al-Rawi N, Kavanagh K. Characterisation of yeasts implicated in vulvovaginal candidosis in Irish women. $\mathrm{Br} \mathrm{J}$ Biomed Sci. 1999;56(2):99-104.

44. Schaller M, Mailhammer R, Grassl G, Sander CA, Hube B, Korting HC. Infection of human oral epithelia with Candida species induces cytokine expression correlated to the degree of virulence. J Invest Dermatol. 2002;118(4):652-7.

45. Li L, Dongari-Bagtzoglou A. Oral epithelium-Candida glabrata interactions in vitro. Oral Microbiol Immunol. 2007;22(3):182-7.

46. Li L, Kashleva H, Dongari-Bagtzoglou A. Cytotoxic and cytokine-inducing properties of Candida glabrata in single and mixed oral infection models. Microb Pathog. 2007;42(4):138-47.

47. Abiko Y, Saitoh M, Nishimura M, Yamazaki M, Sawamura D, Kaku T. Role of beta-defensins in oral epithelial health and disease. Med Mol Morphol. 2007;40(4):179-84.

48. Feng Z, Jiang B, Chandra J, Ghannoum M, Nelson S, Weinberg A. Human beta-defensins: differential activity against candidal species and regulation by Candida albicans. J Dent Res. 2005;84 (5):445-50.

49. Vylkova S, Nayyar N, Li W, Edgerton M. Human beta-defensins kill Candida albicans in an energy-dependent and salt-sensitive manner without causing membrane disruption. Antimicrob Agents Chemother. 2007;51(1):154-61.

50. Helmerhorst EJ, Venuleo C, Beri A, Oppenheim FG. Candida glabrata is unusual with respect to its resistance to cationic antifungal proteins. Yeast. 2005;22(9):705-14.

51. Helmerhorst EJ, Venuleo C, Sanglard D, Oppenheim FG. Roles of cellular respiration, $\mathrm{CgCDR} 1$, and $\mathrm{CgCDR} 2$ in Candida glabrata resistance to histatin 5. Antimicrob Agents Chemother. 2006;50 (3):1100-3.

52. Beckloff N, Laube D, Castro T, et al. Activity of an antimicrobial peptide mimetic against planktonic and biofilm cultures of oral pathogens. Antimicrob Agents Chemother. 2007;51(11):4125-32.

53. Butler G, Rasmussen MD, Lin MF, et al. Evolution of pathogenicity and sexual reproduction in eight Candida genomes. Nature. 2009;459(7247):657-62.

54. Chaerkady R, Harsha HC, Nalli A, et al. A quantitative proteomic approach for identification of potential biomarkers in hepatocellular carcinoma. J Proteome Res. 2008;7(10):4289-98. 
55. Miranda I, Rocha R, Santos MC, et al. A genetic code alteration is a phenotype diversity generator in the human pathogen Candida albicans. PLoS ONE. 2007;2(10):e996.

56. Silva RM, Paredes JA, Moura GR, et al. Critical roles for a genetic code alteration in the evolution of the genus Candida. EMBO J. 2007;26(21):4555-65.

57. Gomes AC, Miranda I, Silva RM, et al. A genetic code alteration generates a proteome of high diversity in the human pathogen Candida albicans. Genome Biol. 2007;8(10):R206.

58. Rodaki A, Young T, Brown AJ. Effects of depleting the essential central metabolic enzyme fructose-1, 6-bisphosphate aldolase on the growth and viability of Candida albicans: implications for antifungal drug target discovery. Eukaryot Cell. 2006;5(8):1371-7.

59. Cowen LE. Hsp90 orchestrates stress response signaling governing fungal drug resistance. PLoS Pathog. 2009;5(8):e1000471.

60. Singh SD, Robbins N, Zaas AK, Schell WA, Perfect JR, Cowen LE. Hsp90 governs echinocandin resistance in the pathogenic yeast Candida albicans via calcineurin. PLoS Pathog. 2009;5(7): e1000532.

61. Muerhoff AS, Birkenmeyer LG, Coffey R, et al. Detection of Plasmodium falciparum, vivax, ovale and malariae MSP1-p19 antibodies in human malaria patients and experimentally infected non-human primates. Clin Vaccine Immunol. 2010. doi:10.1128/ CVI.00196-10

62. Birkenmeyer L, Muerhoff AS, Dawson GJ, Desai SM. Isolation and characterization of the MSP1 genes from Plasmodium malariae and Plasmodium ovale. Am J Trop Med Hyg. 2010;82 (6):996-1003.

63. Gillet P, van Dijk DP, Bottieau E, Cnops L, Van Esbroeck M, Jacobs J. Test characteristics of the SD FK80 Plasmodium falciparum/Plasmodium vivax malaria rapid diagnostic test in a non-endemic setting. Malar J. 2009;8:262.

64. Lima Mda R, Nogueira RM, Schatzmayr HG, dos Santos FB. Comparison of three commercially available dengue NS1 antigen capture assays for acute diagnosis of dengue in Brazil. PLoS Negl Trop Dis. 2010;4(7):e738.

65. Qiu LW, Di B, Wen K, et al. Development of an antigen capture immunoassay based on monoclonal antibodies specific for dengue virus serotype 2 nonstructural protein 1 for early and rapid identification of dengue virus serotype 2 infections. Clin Vaccine Immunol. 2009;16(1):88-95.

66. Junqueira M, Spirin V, Balbuena TS, et al. Protein identification pipeline for the homology-driven proteomics. J Proteomics. 2008;71(3):346-56. 